\title{
Makna Simbolik Komunikasi Merek Kuliner Khas Palembang di Bandung
}

\author{
Agustin Rozalena \\ Program Studi Administrasi Keuangan, Politeknik Piksi Ganesha, Bandung \\ E-mail: agustin.rozalena@piksi-ganesha-online.ac.id
}

\begin{abstract}
Abstrak. Penelitian ini membahas tentang makna simbolik komunikasi merek kuliner khas kota Palembang di Kota Bandung, yaitu empek-empek. Tujuan penelitian untuk mengetahui dan menganalisis secara kualitatif bagaimana makna simbolik merek kedai atau restoran empek-empek yang ada di kota Bandung. Dalam penulisan ini, penulis menggunakan rancangan studi kasus serta menggunakan teknik pengumpulan data pengamatan nonpartisipasi, literatur dan wawancara. Selain itu, teknik analisis data model interaktif. Hasil penelitian menunjukkan bahwa (1) makanan berasal dari Kota Pelembang memiliki sejarah geografis, historis dan filosofis, sehingga membentuk karakter budaya; (2) makna simbolik berdasarkan pemilihan merek empek-empek yang digunakan oleh kedai-kedai di Kota Bandung membantu makanan ini terkenal dan mudah diterima. Makna simbolik juga menunjukkan adanya simbol identitas, budaya, nilai ekonomis, prestise/gaya hidup dan kebiasaan; (3) penciptaan kekuatan merek dan loyalitas merek yang memudahkan nama atau merek kedai diingat dan dipilih pelanggan. Pada kesimpulan, didapatkan bahwa (1) makna simbol tersebut menggambarkan berbagai keunikan dan filosofi yang menyatu dalam pengomunikasian merek ke konsumen; (2) merek empek-empek yang ditampilkan pada kedai atau restoran di Kota Bandung menunjukkan semakin tersebar nama atau merek empek-empek dengan nama lokasi kedai akan menguatkan merek dan loyalitas para pelanggan.
\end{abstract}

Kata Kunci: makna simbolik, komunikasi merek, kuliner Palembang

\begin{abstract}
This study discusses the symbolic meaning of Palembang typical culinary communication brand in Bandung, namely empek-empek. The purpose of research to determine and analyze qualitatively how the symbolic meaning of empek-empek shop or restaurant brand.It used case study design as well as using nonparticipatory observation data collection techniques, literature, and interviews. In addition, interactive model data analysis techniques are also completed. The results showed that: (1) the food originated from Palembang has a history of geographical, historical and philosophical, thus it is forming cultural character;(2) the symbolic meaning based on the selection of empek-empek brand that used by the shop in Bandung helps this food is famous and easy to accept. The symbolic meaning also indicates the existence of identity, culture, economic value, prestige/lifestyle and habits symbols, and (3) creation of brand strength and loyalty will facilitate the name or brand of the shop being remembered and selected by the customer. In conclusion, it is found that: (1) the meaning of symbol describes the uniqueness and philosophy that integrates in communicating the brand to the consumer, and (2) empek-empek brand displayed on the shop or restaurant in Bandung shows when those are spreading widely with the location, it will strengthen the brand and customer loyalty.
\end{abstract}

Keywords: symbolic meaning, brand communication, Palembang culinary 


\section{PENDAHULUAN}

Bandung merupakan salah satu ibu kota provinsi dan kota besar di Indonesia yang akrab dengan keterbukaan terhadap gaya hidup dari luar kota. Terdapat beberapa kekhasan yang menunjukkan kota Bandung sebagai pilihan masuknya budaya dari luar dalam hal ini dalam bentuk kebiasaan. Sebut saja, kuliner, fashion, bahasa, hingga teknologi yang membuat Bandung menjadi terlihat sangat mudah menjadi simbol trend setter berbagai produk barang dan jasa. Hal ini menjadi suatu masukan baru kota yang memang memiliki jargon Bandung Bermartabat. Kondisi tersebut akan berpengaruh terhadap konsep pembangunan citra kota sebagai suatu diferensiasi dengan kota besar lainnya.

Diferensiasi ini dapat dirasakan pengunjungnya melalui bentuk penataan kota, simbol-simbol kota, kekhasan gaya dan fitur, merek yang sesuai dengan harapan masyarakat wisata maupun karakter warga kota tersebut. Artinya, untuk mewujudkan konsep kota wisata sesuai dengan sejarah, sosial, budaya, Kota Bandung juga memiliki hierarki nilai dengan menciptakan, mengomunikasikan, dan memasarkan pariwisata kota melalui sebuah nama atau merk yang mudah diingat dan dikenal,

Salah satu, karakter pariwisata yang sedang dan terus digalakkan adalah kuliner. Kuliner dapat muncul dalam bentuk dan penawaran menu makanan yang berbeda-beda, dengan demikian diharapkan terbuka pasar potensial dan investor. Selain itu, peran pemerintah Kota Bandung perlu bersinergi dengan pengusaha kuliner untuk menata wisata kuliner Nusantara agar pelestarian kuliner nusantara itu sendiri tetap terjaga, sehingga bermanfaat bagi perkembangan kepariwisataan di Kota Bandung. Melalui penataan wisata kuliner yang tepat, wisata kuliner Nusantara dapat menarik wisatawan untuk datang ke Kota Bandung.
Dampak yang ditimbulkan adalah meningkatnya sosial ekonomi masyarakat khususnya pelaku usaha dan menjadi salah satu sumber peningkatan pendapatan asli daerah (PAD) melalui restribusi.

Seperti diketahui, setiap jenis kuliner dapat mewakili simbol komunikasi. Kuliner menjadi salah satu media komunikasi bagi suatu daerah atau kota, misalnya Yogyakarta terkenal dengan nama kota gudeg. Oleh karena itu, mewujudkan wisata kuliner sebagai gaya hidup dan dijadikan industri yang ditangani dengan serius merupakan pembangunan citra kota. Selain dapat membuat petualangan baru bagi para wisatawan juga menjadi potensi untuk meyebarkan kembali merek kuliner tersebut kepada calon wisatawan lainnya.

Kuliner, makanan atau masakan yang dimiliki oleh setiap daerah memiliki kekhasan. Bagi wisatawan, kuliner khas Bandung tetap menjadi pilihan utama, seperti siomay, peuyeum, cilok, colenak, dan sebagainya, namun kedatangan kuliner dari daerah lain, seperti empekempek dari Palembang, nasi padang dari Padang, maupun es pisang ijo dari Makassar menunjukkan bahwa Kota Bandung dapat dijadikan trend setter bertemunya semua kuliner dari seluruh Indonesia. Khususnya, penganan empek-empek ini, penulis menganggap bahwa sajian ini sudah sangat familiar bagi masyarakat Kota Bandung dan mulai menjamur memenuhi sudut Kota Bandung.

Demikian halnya dengan penganan empek-empek yang terbuat dari olahan daging ikan, tepung tapioka dan bumbubumbu ini dianggap sebagai bagian gaya hidup dalam mengonsumsi makanan sehari-hari. Oleh sebab itu, untuk membedakan dengan makanan lainnya, perlu diberikan nama, sehingga memiliki citra dari mana makanan tersebut berasal. Melalui sebutan nama pada makanan tersebut, hubungan makanan dan bahasa 
terjadi.

Nama, merek atau brand merupakan bagian dari penciptaan perbedaan makanan satu dengan lainnya. Adanya merek mengajarkan konsumen untuk mengetahui siapa, apa dan mengapa suatu produk itu harus ada diantara mereka. Demikian halnya dengan keberadaan empek-empek yang memiliki arti lebih dari sekadar makanan yang dikonsumsi bagi penyuka sajian olahan tepung, melainkan menjadikannya sebagai nilai budaya yang dapat dilestarikan. Sejalan dengan uraian tersebut, maka penelitian ini pun bertujuan untuk mengetahui dan menganalisis makna simbolik komunikasi merek kedai atau restoran empek-empek yang di Kota Bandung.

\section{Peran Merek}

Perusahaan maupun industri sekalipun, mereka menjadi hal yang sangat tidak terpisahkan dari tanda kepopuleran sebuah produk. Artinya, sebuah produk sangat bergantung bagaimana penamaan atau merek menjadi cikal bakal pengakuan bagi yang memroduksi dan merasakan manfaat produk itu sendiri sebagaimana yang dijelaskan oleh Lestari, dkk (2017) bahwa,

"Saat ini ada banyak merek yang telah dibesarkan di a industri bisnis baik lokal maupun lokal secara global. Persaingan untuk sebuah perusahaan untuk mendapatkan pengakuan dari konsumen semakin diperketat karena itu. Alizadeh dan rekan (2014) mendefinisikan merek itu sendiri sebagai campuran perusahaan prinsip, nilai produk, dan implisit janji dari korporasi untuk pelanggannya, yang meliputi terlihat dan tak terlihat karakteristik."

Pada prinsipnya, kota merupakan pengejawatahan dari kualitas gaya hidup warganya. Hal ini selaras dengan apa yang disampaikan Koswara (2011),
"Sebuah kota harus memiliki kualitas yang baik untuk mendapatkan kekuatan merknya secara sukses, akan tetapi banyak faktor yang harus tercakup di dalamnya. Kerjasama yang baik antara penduduk kota dengan pemerintah kota adalah salah satu faktor kunci dalam menentukan potensial merk sebuah kota."

Adapun pada pendapat lain mengenai pemerekan kota dinyatakan Rozalena (2014), bahwa pada sebagian besar penamaan atau pemerekan kota selalu dikaitkan dengan promosi kota. Tentu saja hal ini tidak lepas dari bagaimana pemerintah mampu merencanakan pemasaran kota dengan setiap fitur-fitur kota dengan mengombinasikan sejarah, status sosial dan budaya kota seperti yang dijelaskan sebelumnya. Kota dapat dijadikan sebuah hak cipta untuk menunjukkan keunikan kota agar mudah diingat. Kota juga dapat menjadi simbol kualitas yang dapat meyakinkan pengunjung, selain kualitas yang merepresentasikan kepribadian pengunjungnya yang ditunjukkan melalui tampilan-tampilan melalui merek kota. Promosi dengan pilihan media dan saluran komunikasi yang tepat dapat membantu kota itu ditawarkan kepada pengunjung melalui manfaat apa yang diterima sehingga merasakan suatu kepuasan setelah meninggalkan kota tersebut.

Dalam konteks komunikasi pemasaran, perusahaan maupun para pengusaha berusaha menginformasikan, membujuk, dan mengingatkan konsumen secara langsung dan tidak langsung mengenai produk yang dimilikinya. Oleh karena itu, Saidah dan Rozalena (2016) menyatakan bahwa komunikasi pemasaran yang digunakan dalam memasarkan produk yang dihasilkan, diharapkan dapat memberi haisl berupa peningkatan penjualan. Oleh sebab itu, sebelumnya perlu diadakan analisis komponen-komponen komunikasi 
pemasaran yang akan digunakan. Tujuan analisis ini agar pesan yang dirancang tepat sasaran, sehingga target sasaran yang dituju memberikan feedback yang positif.

Pada dasarnya, merek bukan sekadar kumpulan dari identitas, citra dan aspirasi, melainkan suatu alasan mengapa kuliner tertentu harus memiliki nama atau merek. Penamaan atau pemerekan ini dibuat agar berbeda dengan kuliner lainnya, selain memiliki ciri khas. Di sisi lain, penggunaan frasa komunikasi merek merupakan pemahaman yang mengarahkan sarana yang digunakan pengusaha dalam upaya menginformasikan, membujuk dan mengingatkan konsumen langsung atau tidak langsung tentang produk dan merek yang ditawarkan.

Dengan kata lain, masih menurut Entaswara, (2008:260), "Komunikasi merek bertujuan membangun merek melalui komunikasi pemasaran menuju penciptaan brand equity dan brand loyalty. Brand equity adalah kekuatan merek dalam menghadapi persaingan antar kota terutama dalam menggaet wisatawan yang ketat. Oleh karena itu, merek yang kuat merupakan suatu pembeda yang jelas, bernilai, dan bersinambungan, sehingga menjadi ujung tombak bagi daya saing dan sangat membantu dalam strategi pemasaran. Brand equity mengacu pada nilai jasa, gambaran kualitas dan keuntungan sehingga menambah nilai pada produk bagi perusahaan atau pelanggannya. Adapun brand loyalty merupakan kesan atas merk yang melekat kuat dalam memori pelangan dan membenttuk kesetiaan merk tersebut."

Adapun citra merk diidentikkan dengan apa yang diwakilkan oleh merek makanan itu. Citra merek pada akhirnya akan menumbuhkan kesadaran konsumen untuk memilih makanan yang diinginkannya. MenurutKotlerdanKeller,
(2008) kesadaran merek merupakan kemampuan untuk mengidentifikasi dalam kategori-kategori. Komunikasi pemasaran memungkinkan perusahaan menghubungkan merek mereka dengan orang, tempat, acara, merek, pengalaman, perasaan, dan hal lainnya. Masih menurut Kotler \& Keller (2009), perusahaan dapat berkontribusi pada ekuitas merek dengan menanamkan merek dalam ingatan dan menciptakan citra merek, serta mendorong penjualan, bahkan mempengaruhi nilai pemegang saham. Hal ini menunjukkan bahwa pengunjung kuliner atau penikmat makanan potensial dapat mengakui dan mengingatnya melalui slogan atau merek secara terperinci.

\section{Kuliner khas kota}

Pada kenyataannya, pola kebiasaan seseorang atau masyarakat tertentu juga sangat mempengarui pola produksi makanan tradisional menuju modern. Walhasil, jika tersedia banyak foodcourt di supermal, bukan berarti kedai-kedai atau restoran pinggir jalan tidak dapat menampung lagi makanan tradisional. Oleh sebab itu, kuliner sudah menjadi kehidupan warga kota seperti yang dinyatakan Misnawati (2017) bahwa kuliner adalah suatu bagian hidup yang erat kaitannya dengan konsumsi makanan sehari-hari. Dalam pandangan masyarakat awam, makanan apa pun yang disantap dalam kehidupan sehari-hari seseorang atau kelompok menujukkan adanya kontribusi informasi yang disampaikan makanan atau penganan tersebut dalam bentuk pesan, baik kognisi, afeksi maupun konasi seseorang.

Kuliner atau makanan merupakan pembentuk identitas etnik atau lambang bangsa/suku melalui masakan etnik yang mempunyai karakateristik rasa khusus, seperti halnya empek-empek. Makna simbolik yang terkandung dalam kuliner khas ini menurut Misnawati (1917) juga dapat dilihat dari peran simbol 
pengetahuan karena ketika seseorang berbicara tentang makanan, maka secara disadari atau tidak, seseorang akan memberikan pengetahuan dan terjadi pertukaran pengetahuan antara individu. Pengetahuan yang dimaksud dapat berupa pengetahuan tentang identitas, asal muasal, bahan makanan, gizi, dan lain sebagainya.

\section{Teori Interaksionisme Simbolik}

Saat berkomunikasi, seseorang akan membawa makna melalui apa yang diciptakannya dalam pikiran, perasaan dan tindakannya kepada orang lain. Makna yang diberikan pada simbol merupakan produk dari hasil interaksi sosial dan menggambarkan kesepakatan untuk menerapkan makna tertentu pada simbol tertentu. Makna akan ada saat orang-orang memiliki interpretasi yang sama mengenai simbol-simbol yang mereka pertukarkan.

Komunikasi yang terjadi antarmanusia memungkinkan banyak makna dari setiap simbol yang dipeerankan oleh pelakunya. Hal ini senada dengan pendapat Mulyana (2012) bahwa komunikasi yang dilakukan oleh manusia, memiliki prinsip dan hakikat yang perlu diperhatikan, yaitu: (a) Komunikasi adalah proses simbolik; (b) Setiap perilaku manusia berpotensi sebagai komunikasi; (c) Komunikasi memiliki dimensi isi dan dimensi hubungan; (d) Komunikasi berlangsung dalam berbagai tingkat kesengajaan; (e) Komunikasi terjadi dalam kontek ruang dan waktu; (f) Komunikasi melibatkan prediksi peserta komunikasi; (g) Komunikasi bersifat sistemik. (h) Semakin mirip latar belakang budaya peserta, komunikasi semakin efektif; (i) Komunikasi bersifat nonsekuensial; (j) Komunikasi bersifat dimanis, prosesual, dan transaksional; (k) Komunikasi bersifat irreversible; (1) Komunikasi bukan panasea yang dapat menyelesaikan berbagai masalah.
Teori interaksionisme simbolik adalah hubungan antara simbol dan interaksi. Menurut George Herbert Mead, orang bertindak berdasarkan makna simbolikyangmunculdalam sebuah situasi tertentu. (West dan Turner, 2008:96). Adapun simbol adalah representasi dari sebuah fenomena, dimana simbol sebelumnya sudah disepakati bersama dalam sebuah kelompok dan digunakan untuk mencapai sebuah kesamaan makna bersama.

Ralph Larossa dan Donald C. Reitzes (1993) seperti dikutip oleh West and Turner (2007:96) mengatakan bahwa interaksi simbolik adalah sebuah kerangka referensi untuk memahami bagaimana manusia bersama dengan orang lainnya menciptakan dunia simbolik dan bagaimana dunia ini, sebaliknya membentuk perilaku manusia.

Pandangan tersebut menunjukkan bahwa interaksi simbolik adanya keterkaitan apa saja yang dipikirkan oleh seseorang (mind) dan semua hal yang mengenai diri (self), bahkan hubungan yang dibangun dengan berbagai komponen yang ada di tengah tatanan masyarakat (society). Ketiga hal tersebut menjadi satu kesatuan yang pada akhirnya membentuk interaksi sosial. Oleh pendukung interaksi simbolik, maka tujuan dari keberadaan seseorang di tengah kehidupan sosial tersebut dapat memediasi dan menginterpretasi makna apa yang sudah disampaikan seseorang saat ia berada di tengah masyarakat (society). Makna yang muncul merupakan hasil dari interaksi itu sendiri. Dengan demikian, adanya makna dikarenakan adanya hubungan interaksi dengan pihak lain.

\section{METODE PENELITIAN}

Penelitian mengenai komunikasi merek kuliner ini dilakukan melalui pendekatan kualitatif dengan metode studi kasus. Peneliti berusaha mengetahui 
dan menganalisis bagaimana komunikasi merek empek-empek ini memiliki makna simbolik bagi pengunjung yang sekaligus penikmat empek-empek di kedaikedai atau restoran yang ada di Kota Bandung. Prosedur penelitian kualitatif menghasilkan data deskriptif berupa katakata tertulis atau lisan dari orang-orang dan perilaku yang diamati. (Moleong, 2012:4)

Melalui penelitian kualitatif, peneliti dapat mengenali subjek dan merasakan apa yang mereka alami dalam kehidupan sehari-hari. Metode kualitatif memperlakukan data yang sebagai sesuatu yang bermakna, sehingga dapat mengetahui makna simbolik dari penamaan empek-empek yang dijual di kedai-kedai.

Selain itu, penelitian ini mengutamakan data primeryang diperoleh secara langsung dari lapangan, melalui wawancara mendalam, pengamatan non-partisipatif dan studi literatur. Berdasarkan hal itu pula, penulis dapat menemukan dan mengetahui pandangan, kejadian, kegiatan, pendapat perasaan dari narasumber tentang komunikasi merek kuliner khususnya makanan khas Kota Palembang ini saat dipasarkan di Kota Bandung.

Para informan dalam penelitian ini sejumlah 10 orang yang terdiri atas empat informan kunci sebagai pengelola kedai empek-empek di Kota Bandung. Adapun enam informan lainnya merupakan konsumen dari masing-masing kedai atau resto empek-empek yang kerap dikunjungi. Berdasarkan fokus penelitian yang sudah dijelaskan sebelumnya, untuk menganalisis data penulis menggunakan analisis data kualitatif secara interaktif.

\section{TEMUAN DAN PEMBAHASAN} Simbol Makanan Khas Empek-Empek

Secara geografis dan historis, nama khas penganan dari kota Palembang ini kerap disebut pempek atau empek-empek.
Empek-empek merupakan penganan khas terbuat dari daging ikan segar yang digiling halus yang dicampur dengan tepung tapioka/sagu disertai bumbubumbu. Empek-empek dapat dimasak dengan cara direbus, digoreng maupun dipanggang.

Terdapat berbagai jenis-jenis empek-empek, baik berukuran besar seperti kapal selam, lenjer dan lenggang Adapun empek-empek berukuran kecil, seperti telur kecil, iris (lenjer yang dipotong), bulat (ada'an), keriting/ kerupuk, tahu, kulit, pistel (isi papaya muda yang ditumis) dan panggang. Menikmati empek-empek dapat dinikmati dengan cara sekadar mencocol didalam cuko atau menyuruputnya melalui bibir piring kecil. Cuko sendiri, yaitu saus encer berbahan gula aren yang dimasak bersama air, cabai rawit dan bawang putih giling, perasan asam jawa, ebi (udang rebon) dan garam.

Pelafalan atau penyebutan makanan ini disesuaikan dengan kemudahan siapapun yang menyebut nama tersebut. Sebagai contoh, di tempat asalnya, di Kota Palembang, lebih banyak memilih kata pempek dibandingkan empekempek (mpek-mpek) yang tersebar di beberapa kota di luar kota Palembang, termasuk Bandung. Penyebutan nama ini menjadi suatu simbol tersendiri bagi akulturasi budaya seperti yang disebutkan Misnawati (2017),

"Nama empek-empek/pempek telah ada di Palembang sejak masuknya perantau Cina sekitar abad ke-16. Akulturasi budaya ini mengantarkan nama pempek atau empek-empek tidak terlepas dari kebiasaan masyarakat sekitar menyebut nama "apek" sebagi sebutan untuk lelaki tua keturunan Tionghoa. Pembiasaan menyebut nama seseorang dengan, "Pek, Pek, Pek," merupakan informasi kuat untuk menyatakan bahwa itulah asal nama sajian ini," 
Informasi tersebut menunjukkan adanya nilai filosofis yang terkandung dari nama, produksi berupa bahan baku, penyajian, pemasaran, dan perilaku kebiasaan sebagai nilai budaya dan sosial masyarakat. Makna filosofis tesebut yang mencakup (1) nama dan cikal bakal awal mula keberadaan kuliner khas.

Penamaan empek-empek merupakan cerita yang sudah ada sejak abad ke-16, yaitu berasal dari nama pendatang keturunan Tionghoa. Maknanya adalah kaitan sisi emosional warga pendatang dengan penduduk lokal (pribumi) yang merupakan kepaduan dalam akulturasi budaya. (2) Empekempek merupakan sajian yang merupakan makanan basah terbuat dari daging ikan olahan dengan campuran beberapa materi lainnya.

Filosofi yang muncul adalah bagaimana cara mengolah semua bahan yang mengandung sifat alamiah dari bahan dasar alam berupa ikan yang dapat dimaknai sebagai menghargai karunia Tuhan dan memanfaatkannya sebagai makanan sehari-hari. Selain itu, adanya sifat kebudayaan yang menjadi tatanan kehidupan perilaku masyarakat Palembang dan sekitarnya sebagai ciri khas adat kebiasaan.

Paduan dari dua sifat alamiah tersebut menunjukkan kepaduan unsur alam yang saling bersinergi atau merupakan makanan yang dapat dikonsumsi untuk kelangsungan hidup orang yang menikmatinya. Kedai maupun restoran di Bandung tetap melakukan proses pengolahan sama seperti yang dilakukan di tempat asalnya. (3) Empekempek termasuk makanan yang disajikan dengan menggunakan satu pinggan atau piring yang didalamya terdapat beberapa macam empek-empek kemudian di sampingnya disertakan mangkuk kecil berisi cuko. Pada masyarakat asli Palembang, cara memakan empek- empek hanya menggunakan tangan atau tidak menggunakan sendok atau garpu. Selain itu, cara penyajian yang harus menghindangkan pada satu hidangan untuk 6-8 orang terutama untuk sajian pesta pernikahan atau kenduri keluarga. Adapun penyajian yang dilakukan oleh kedai di Kota Bandung menyajikan relatif sama dan tidak ada perbedaan. Kedai hanya menyajikan empek-empek dengan menyertakan garpu atau sendok bagi konsumen yang enggan menggunakan tangan untuk menyantapnya. Nilai filosofinya adalah empek-empek merupakan makanan yang memiliki kebiasaan melekat pada penikmatnya, sehingga menjadi tanda atau simbol.

Adapun pada kota lain, kerap menggunakan sendok atau garpu menunjukkan bahwa keberadaan makanan ini dapat disajikan secara fleksibel selain menjadi pelengkap dari seluruh makanan yang disajikan oleh masyarakat asalnya. (4) empekempek merupakan makanan yang dapat dinikmati tanpa mengenal waktu. Artinya, pada waktu kapan pun dapat disantap meskipun tanpa menambahkan cuko atau saus khas pelengkap empekempek. Penambahan cuko sebagai saus ini sangat praktis dikarenakan dapat disesuaikan dengan penikmat empekempek itu sendiri. Waktu makan juga berhubungan dengan saat dimakan bersama-sama seluruh anggota keluarga. Filosofinya adalah kebersamaan dalam kenikmatan itu adalah suatu tradisi yang dapat dirasakan hingga turun temurun.

Selain itu, nilai folosifis yang dapat diketahui dari waktu ini juga menunjukkan bahwa empek-empek sangat mudah dipasarkan dan diperjualbelikan. Tidak ada hambatan saat harus dipasarkan melalui berbagai media apa pun dan mengikuti bentuk promosi yang sama dengan penganan lainnya. Hal ini juga menunjukkan bahwa masyarakat Kota Bandung tidak antipasti terhadap produk 
dari kota lain, sehingga setiap pengusaha empek-empek di Kota Bandung dapat membuka kedainya menyesuaikan waktu beraktivitas, baik pagi, siang maupun malam masih dapat ditemui.

\section{Simbol Penamaan Merek Empek-Empek}

Selain ketiga aspek tersebut, empek-empek memiliki simbol yang menjadikan penganan ini memiliki citra kuliner yang tetap khas di manapun termasuk keberadaan di setiap kedai di Bandung. Simbol merek di kota Bandung berbeda dengan pemberian merek di kota asalnya, Palembang.

Di Kota Bandung, merek empekempek cenderung ditambahkan dengan nama kota, yaitu Palembang, sehingga dibaca menyatu "empekempek Palembang". Setelah itu, barulah dlengkapi dengan nama atau merek yang melekat, seperti "Pak Anang", "Pempek Faisal", "Pempek Rico", "12 Ulu", "Rama" maupun "Pak Raden".

Semua nama atau merek tersebut menunjukkan simbol komunikasi yang merupakan pengejawantahan dari beberapa simbol yang membentuk makna didalamnya. Pertama, simbol penamaan tersebut yaitu simbol jatidiri yang selalu menyertakan nama kota Palembang sebelum menempatkan merek.

Jatidiri ini bermakna dua sisi. Satu sisi bermakna menunjukkan kuliner lokal, merupakan jenis makanan sehari-hari yang dapat dikomersialkan, serta representasi budaya atau etnis dimana asal empek-empek beras, yaitu Palembang. Di sisi lain, makna yang sangat melekat pada pemilik kedai yang menjadi pembeda dengan kedai lainnya. Meski demikian, nama belakang yang tidak disebutkan pada kata empek-empek tetap menunjukkan identitas makanan. Artinya, makanan yang dihargai sebagai lambang jatidiri suku/bangsa merupakan makanan yang berasal atau dianggap berasal dari kelompok itu sendiri.
Praktiknya, kebanyakan pengusaha kedai empek-empek merupakan orang asli atau yang mengetahui dan mengenal suku Palembang itu sendiri.

Kedua, adanya simbol kultur. Makna simbol budaya terlihat dari nama ataumerekyangdipilihtidakmeninggalkan nama asli penganan, yaitu pempek atau empek-empek. Nilai kebiasaan atau kultur yang sudah menjadi satu kesatuan mulai dari asal penamaan, produksi kali pertama, pemasaran di kota setempat maupun kebiasaan memakan dan pola menghargai saat makan secara bersamasama menunjukkan penerimaan budaya dari luar Bandung, yaitu Palembang yang dengan mudah diterima oleh masyarakat Kota Bandung. Makanan khas yang tetap disebutkan nama aslinya ini merupakan citra tradisional yang dimunculkan secara filosofis dengan penggunaan bahan masakan, pengolahan dan penyajian. Proses pembuatan empek-empek hingga penyajian yang masih melibatkan fungsi tradisional asalnya menunjukkan bahwa adanya tradisi budaya dalam kehidupan sebuah masyarakat.

Ketiga, dalam tradisi yang sudah mendarah daging pada masyarakat asal, maka ekspansi usaha dapat dilakukan pada daerah lain, konsep pemasaran dan pemerekan pada penganan ini menjadi sebuah simbol nilai ekonomi. Makna simbol ekonomis terlihat dari banyaknya kedai yang dibuka di Kota Bandung. Hal ini menunjukkan adanya ide kreatif dan modal yang memadai mebuat penganan ini dianggap mudah dipasarkan. Demikian halnya dengan perbandingan harga yang dianggap lebih mahal dibandingkan dengan harga di tempat asalnya. Penyesuaian harga ini membuat empek-empek memiliki nilai ekonomis yang tinggi. Pemerekan dengan munculnya brand, menjadi sebuah tolok ukur komunikasi merek kepada konsumen.

Keempat, bagi masyarakat kota 
Bandung, empek-empek bukanlah makanan penganan yang baru dan aneh, sehingga menjadi mudah diterima dan dinikmati. Nilai karya yang ditunjukkan dalam mengolah, membentuk dan menyajikan empek-empek sebagai kuliner yang memiliki nilai relasi yang dibangun di antara warga lokal dengan pendatang. Oleh sebab itu, nilai relasi tersebut mengandung simbol sosial. Kekuatan nilai sosial yang muncul adalah terbentuknya komunitas yang salaing mendukung untuk menudukung masyarakat kota Bandung.

Kelima, pengusaha enpek-empek membuka kedainya sudah merambah kalangan kelas menengah keatas yang banyak mencari makanan di mal maupun restoran dengan layanan paripurna. Makna simbol gaya hidup yang muncul ini lebih cenderung pada kesan lebih trendi dan terbuka untuk semua kalangan status sosial. Dalam hal ini, bagi sebagian besar konsumen penikmat empek-empek menerima apabila harga satu buah empek-empek di Kota Bandung termasuk kategori mahal dibandingkan empekempek yang berada di tempat asalnya, yang masih mematok harga dikisaran Rp1.000,00 per buah.

Untuk membeli satu buah empekempek telur kecil atau adaan (model bakso), dapat dihargai Rp6.000,00$16,000,00$ sesuai dengan kualitas bahan dan kondisi kenyamanan kedai. Hal ini akan berbeda dengan empek-empek yang kurang memiliki kualitas bahan yang lebih baik, misalnya kurang atau sidkit ikan giling yang dipakai, sehingga mengurangi cita rasa dan dijual di pinggir jalan dengan gerobak dorong atau jongko akan dibandrol dengan harga Rp2.000,00Rp3.000,00 perbuah. Perbedaan harga ini menunjukkan bahwa terdapat nilai ekonomis yang tinggi dalam memilih jenis makanan melalui tanda dan status sosial seseorang.

Keenam, kultur yang sudah berpadu dari makanan pendatang menjaid makanan yang dapat dikonsumsi setiap waktu oleah maysrakat Kota Bandung menyatakan simbol pembiasaan dalam mengonsumsi dan memasarkan. Makna dari simbol pembiasaan ini terlihat dari masyarakat Kota Bandung yang sudah mulai memilih makanan ini sebagai alternatif kuliner sehari-hari yang bisa dinikmati setiap hari, bahkan setiap saat. Hal ini tampak dari bertambahnya kedai atau restoran empek-empek di jalan-jalan utama kota. Keberadaan kedai ini dimaknai bahwa empek-empek mulai menjadi kebiasaan makan yang menunjukkan kegiatan ekspresif yang memperkuat kembali hubungan-hubungan dengan kehidupan sosial. Makna lainnya dari simbol pembiasaan adalah warga Bandung tidak bosan di makan setiap hari. Sama halnya ketika mereka dapat menikmati sajian khas Kota Bandung, seperti siomay, cilok, dan lain sebagainya. Penyamaan makanan untuk konsumsi setiap waktu, tempat dan cara mendapat makanan tersebut menunjukkan adanya integrasi dengan diri individu.

\section{Penciptaan Brand Equity dan Brand Loyalty}

Berdasarkan pengamatan dan hasil penelitian diketahui bahwa setiap merek empek-empek merupakan nama yang sama dengan kedai atau restoran dimana empek-empek dijual maupun dipasarkan. Nama atau merek pada dasarnya disesuaikan dengan pengusaha yang mengenalkan empek-empek melalui kedainya. Informan dari merek Pempek 12 Ulu menyebutkan bahwa nama disebutkan dipilih untuk menunjukkan nama lokasi di salah satu lokasi yang sangat terkenal di Kota Palembang, yaitu kawasan 12 Ulu. Demikian halnya dengan pempek Pak Raden yang dibawa dari kedai yang ada di Palembang yang berada di kawasan pusat kota. Keunikan nama Pak Raden membuat konsumen lebih mulai menyebut dan melakukan 
word of mouth ke seluruh penikmat empek-empek di kota Bandung.

Adapun nama atau merek empekempek yang memang dikreasikan oleh warga Bandung sendiri adalah dengan menyertakan nama jalan, serti jalan Rama, sehingga memberi nama Pempek Rama. Kesan nama atau merek ini menjadi sangat mudah dikenal masyarakat yang membuat mereka lenih mudah pula menjangkau tempat dan menikmati empek-empek sesuai dengan waktu dan tingkat sosial mereka.

Nama atau merek empek-empek ini dipilih untuk memudahkan pula menanamkan brand equity atau kekuatan merek dalam menghadapi persaingan antar kedai terutama dalam menggaet konsumen. Hal ini menunjukkan pula semakin dikenalnya nama-nama kedai tersbeut seuai dengan kualitas empekempek yang dijual. Semakin empekempek dikenal dan dirasakan warga, sehingga menjadikan makanan ini sebagai alternatif wisata kuliner. Pihak pengusaha kedai membuat sebuah kesan atas merek yang melekat kuat dalam memori pelanggan dan membentuk kesetiaan merek tersebut melalui keunikan nama atau merek, seperti menyertakan nama lokasi/kawasan, nama pengusaha itu sendiri, nama jalan tempat kedai berada, maupun nama tokoh/tokoh yang dikenal.

Bagi suatu kota, kuliner merupakan gaya hidup yang dapat dikreasikan menjadi suatu model kuliner. Oleh karena itu, keberadaan kuliner menjadi pelengkap pariwisata kota atau daerah utnuk menonjolkan keunikan dan kekhasan melalui sajian penganan atau makanan yang bernilai ekonomis, sosial maupun gaya hidup bagi siapa pun yeng berkunjung. Munculnya program wisata kuliner dalam bentuk agenda wisata kuliner memungkinkan adanya peran komunikasi merek kuliner.

\section{SIMPULAN}

Simpulan yang dapat disampaikan dalam penelitian ini, yaitu: (1) makna simbolik dari empek-empek dapat dilihat berdasarkan simbol identitas, budaya, nilai ekonomis, sosial, prestise dan gaya hidup, serta kebiasaan. Makna simbol tersebut menggambarkan berbagai keunikan dan filosofi yang menyatu dalam mengomunikasikan merek ke konsumen terutama di kota Bandung. (2) Komunikasi merek merupakan bagian komunikasi pemasaran juga memiliki persamaan dengan proses komunikasi pada umumnya. Hal ini menjadi bagian yang penting, saat pengusaha empekempek mencoba memilih nama atau merek empek-empek saat penganan ini masuk ke kota Bandung atau daerah lainnya.

\section{DAFTAR PUSTAKA}

Anita, Sumarni Bayu. (2015). Pempek. Jakarta: Ghalia Indonesia, hal 56.

Estaswara. (2008). Think IMC. Efektivitas Komunitas untuk Menciptakan Loyalitas Merek dan Laba Perusahaan. Hal 335-348. Jakarta: Gramedia Pustaka Utama.

Kellner, Douglas. (2015). Budaya Media; Cultural Studies. Identitas, dan Politik antara Modern \& Postmodern (terjemahan: Galih Bondan Rambatan). Yogyakarta: Jalasutra.

Kliatchko, J. (2002). Understanding Integrated Marketing Communication. Inkwell Publishing.

Koswar, Aang. (2011), City's Branding Ala Munich, dalam Atwar Bajari \& S. Sahala Tua Saragih (eds), Komunikasi Kontekstual. Bandung: Remaja Rosada Karya, hal 335.

Lestari, Heny Wahyu Tamara Dwi., Dindin Dimyati, dan Mohammad Shihab. Strategic Communications and Corporate Branding: A Study of Jebsen \& Jessen Indonesia Group. MediaTor, Vol. 10 (1), Juni 2017, hal 37-52.

Kotler, Philip. (2008). Manajemen Pemasaran: Analisis, Perencanaan, 
Implementasi, dan Control, Edisi bahasa Indonesia. Jakarta: Prenhalindo, hal 213, 172-173.

Misnawati, Desy. (2017). Disertasi Pascasarjana Program Studi Ilmu Komunikasi Universitas Padjadjaran. Kuliner Sebagai Simbol Komunikasi. Bandung: Unpad, hal 54.

Mulyana, Deddy. (2012). Pengantar Ilmu Komunikasi, Suatu Pengantar. Bandung: Remaja Rosdakarya, hal 91. Rozalena, Agustin. (2014). $1^{\text {st }}$ Piksi International Conference on
Knowledge and Sciences 2014 Proceeding. The Pattern of Integrated City Brand Communication, 18-19 November, Bandung, hal 64.

Sahala Tua Saragih (Ed), Komunikasi Kontekstual. Bandung: Remaja Rosada Karya, hal 335.

Saidah, Iis dan Agustin Rozalena. (2016). Jurnal Ekbis. Strategi Komunikasi Pemasaran Aneka Rak Plastik Tritunggalika Kabupaten Bandung. Bandung, hal 74-83. 